\title{
Kematangan Emosi, Problem-Focused Coping, Emotion-Focused Coping dan Kecenderungan Depresi pada Mahasiswa Tahun Pertama
}

\author{
Amalia Nur Aisyah Tuasikal ${ }^{1}$ E Sofia Retnowati ${ }^{2}$ \\ Fakultas Psikologi Universitas Gadjah Mada
}

\begin{abstract}
This research aimed to examine the correlation between emotional maturity, problem-focused coping, and emotion-focused coping in depression among first year college students. It was hypothesized that emotional maturity, problem-focused coping, and emotion-focused coping correlate with the tendency of depression among first year college students. Participants were 214 college students in Yogyakarta (male=66; female=148). Multiple regression analysis showed that emotional maturity and emotionfocused coping contributed significantly to first year college students depression with $19 \%$ contribution $\left(R^{2}=0.19 ; p<0.05\right)$. Emotional maturity negatively correlated with depression tendency $(t=-6.026 ; p<0.05)$, while emotion-focused coping positively correlated with first year college students depression tendency $(t=2.265 ; p<0.05)$. Result showed that problemfocused coping has no significant relationship with depression tendency $(t=-0.557 ; p>0.05)$.
\end{abstract}

Keywords: problem-focused coping, depression; emotional maturity; emotion-focused coping

Abstrak. Penelitian ini bertujuan untuk mengetahui peran kematangan emosi, problemfocused coping, dan emotion-focused coping terhadap kecenderungan depresi pada mahasiswa tahun pertama. Hipotesis penelitian ini adalah kematangan emosi, problem-focused coping, dan emotion-focused coping berkorelasi dengan kecenderungan depresi pada mahasiswa tahun pertama. Partisipan penelitian merupakan 214 mahasiswa tahun pertama di Daerah Istimewa Yogyakarta. Analisis regresi berganda menunjukkan bahwa kematangan emosi dan emotion-focused coping berperan sebesar 19\% pada depresi mahasiswa tahun pertama $\left(R^{2}=0,19 ; p<0,05\right)$. Kematangan emosi terbukti berkorelasi negatif dengan kecenderungan depresi $(t=-6,026 ; p<0,05)$, sedangkan emotion-focused coping berkorelasi positif dengan kecenderungan depresi $(t=2,265 ; p<0,05)$ pada mahasiswa tahun pertama. Hasil penelitian menemukan bahwa problem-focused coping tidak berkorelasi dengan kecenderungan depresi pada mahasiswa tahun pertama $(t=-0,557 ; p>0,05)$.

Kata kunci: depresi; emotion-focused coping; kematangan emosi; problem-focused coping

Penderita gangguan jiwa di Indonesia mengalami peningkatan setiap tahunnya. Hasil Riset Kesehatan Dasar (Riskesdas)
Kemenkes tahun 2013 menemukan bahwa prevalensi gangguan mental emosional yang ditunjukkan dengan gejala-gejala

\footnotetext{
${ }^{1}$ Korespondensi mengenai isi artikel ini dapat dilakukan melalui amaliatuasikal@gmail.com

2 atau melalui sofi 53@ugm.ac.id
} 
depresi dan kecemasan untuk usia 15 tahun ke atas mencapai sekitar 14 juta orang atau $6 \%$ dari jumlah penduduk Indonesia (IDI, 2016). Berdasarkan data WHO, Indonesia berada di urutan keempat negara dengan gangguan depresi terbesar (McPhillips, 2016).

Depresi merupakan gangguan suasana perasaan yang ditandai dengan perasaan sedih yang menetap dan hilangnya minat dalam aktivitas yang disenangi, didampingi dengan ketidakmampuan untuk melakukan aktivitas sehari-hari kurang lebih selama 2 minggu (WHO, 2016). PPDGJ-III (Maslim, 2013) membagi depresi dalam derajat berbedabeda (ringan, sedang, dan berat) yang ditandai dengan kemunculan gejala utama, yaitu afek depresif, kehilangan minat dan kegembiraan, serta berkurangnya energy yang menuju meningkatnya keadaan mudah lelah (rasa lelah yang nyata sesudah kerja sedikit saja) dan menurunnya aktivitas. Gejala lain dari depresi yang disebutkan dalam PPDGJ-III, antara lain: (1) konsentrasi dan perhatian berkurang, (2) harga diri dan kepercayaan diri berkurang, (3) gagasan tentang rasa bersalah dan tidak berguna, (4) pandangan masa depan yang suram dan pesimistis, (5) gagasan atau perbuatan yang membahayakan diri atau bunuh diri, (6) tidur terganggu, dan (7) nafsu makan berkurang. Semakin banyak dan berat simtom yang muncul mengindikasikan semakin berat depresi yang dialami.

Hampir semua orang pernah mengalami depresi, setidaknya dalam bentuk yang lebih ringan. Depresi yang muncul biasanya merupakan respon normal yang muncul terhadap pengalaman hidup negatif. Carson \& Butcher menjelaskan bahwa gejala depresi normal yang terjadi pada individu, jika dapat diatasi dengan baik, nantinya dapat menjadikan individu yang lebih dewasa dan matang (Aditomo \& Retnowati, 2004). Depresi menjadi abnormal ketika gejala yang dialami terjadi dalam waktu yang lama dan cenderung menetap.

Tanda peningkatan depresi muncul antara usia 13-15 tahun kemudian mencapai puncaknya pada usia 17-18 tahun, dan setelah itu menjadi stabil pada usia dewasa (Darmayanti, 2008). Depresi yang terjadi pada remaja seringkali tidak disadari karena remaja ragu untuk menyatakan perasaannya dan jarang mencari bantuan dari tenaga profesional. Selain itu, perubahan perilaku yang terjadi pada remaja juga sering diartikan sebagai perubahan hormonal yang normal (Nagendra, Sanjay, Gouli, Kalappanavar, \& VinodKumar, 2012).

Pada usia remaja, salah satu situasi yang dapat menyebabkan depresi adalah stres dalam perkuliahan. Rossiana (2011) menemukan bahwa masih banyak mahasiswa yang belum mampu menyesuaikan pola belajarnya dengan tuntutan kondisi perkuliahan, terkejut dengan rentang waktu belajar yang panjang dan berbeda, serta tidak dapat mengatur waktu antara belajar, berorganisasi dan kuliah. Hal tersebut dapat meningkatkan stres yang dapat menjadi salah satu penyebab masalah psikologis pada mahasiswa baru (Bouteyre, Maurel, \& Bernaud, 2007). Dyson dan Renk (2006) menemukan bahwa tingkat stres yang dialami mahasiswa baru dalam perkuliahannya berasosiasi dengan simtom depresi, semakin tinggi tingkat stres pada perubahan di perkuliahan maka semakin tinggi pula depresi yang dialami.

Banyak faktor yang dapat menyebabkan terjadinya depresi yang dibedakan menjadi dua: faktor internal dan faktor eksternal. Faktor internal meliputi faktor genetik, struktur neurologis otak (Dobson 
\& Dozois, 2008), hormonal (Piccinelli \& Wilkinson, 2000), perbedaan gender (Darmayanti, 2008), kematangan emosi (Winnicott, 1990), strategi koping yang digunakan (dalam Bouteyre, Maurel, \& Bernaud, 2007), dan lain-lain. Faktor eksternal meliputi pengalaman traumatis yang dialami, parenting, rendahnya dukungan sosial (Dobson \& Dozois, 2008), lingkungan (Asmika, Harijanto, \& Handayani, 2008), permasalahan medis, dan lain-lain. Dalam penelitian ini, peneliti berfokus pada faktor internal penyebab depresi, yaitu kematangan emosi dan koping.

Mahasiswa tahun pertama mengalami peningkatan secara emosional karena transisi dan penyesuaian terhadap lingkungan. Pengendalian emosi yang baik menjadikan remaja dapat beradaptasi serta mendapatkan penerimaan dari lingkungan sekitarnya. Sharma (2012) menyebutkan bahwa penyesuaian yang dilakukan mahasiswa tahun pertama dapat menyebabkan ketidakstabilan emosi. Ketidakstabilan emosi yang intens, tidak terkontrol, dan irasional dapat meningkat menjadi gangguan emosional di masa mendatang, salah satunya adalah depresi.

Hurlock (1999) mendefinisikan kematangan emosi sebagai keadaan tidak meledaknya emosi individu, tetapi menunggu waktu dan tempat yang tepat untuk memunculkan emosi tersebut dengan cara yang dapat diterima oleh lingkungan. Individu yang matang secara emosi memiliki kontrol penuh terhadap ekspresi dari perasaannya dan menunjukkan perilaku berdasarkan norma sosial yang berlaku (Rani, Kamboj, Malik, \& Kohli, 2015). Individu memiliki kemampuan untuk berpikir secara lebih objektif dan tidak mudah menunjukkan emosi secara berlebihan dihadapan orang lain serta memiliki reaksi emosi yang stabil. Ketidakmatangan emosi ditandai dengan mudahnya individu dalam mengekspresikan emosinya secara berlebihan dihadapan orang lain dan reaksi emosional yang muncul cenderung tidak stabil (Hurlock, 1999).

Mosley, et al. (1994) menemukan bahwa salah satu faktor yang memengaruhi depresi pada mahasiswa adalah strategi koping yang digunakan. Dalam masa transisi, mahasiswa akan dapat menyesuaikan diri dan menjalani kehidupannya di kampus dengan baik jika mampu mengatasi permasalahan yang dihadapinya. Mahasiswa yang tidak mampu mengatasi stres dan tekanan akan cenderung menghindar dari kegiatan yang menimbulkan stres dan tekanan tersebut. Strategi koping yang baik diperlukan oleh mahasiswa agar dapat mengatasi permasalahannya.

Pemilihan strategi koping yang digunakan dapat memengaruhi tingkat depresi. Lazarus dan Folkman membedakan strategi koping menjadi dua, yaitu problem-focused coping yang dilakukan dengan cara mengambil langkah untuk menghadapi masalah secara langsung (Lo, 2002) dan emotion-focused coping dilakukan dengan cara mengelola respon emosional yang muncul ketika menghadapi keadaan yang menimbulkan stres (Dyson \& Renk, 2006). Berdasarkan hasil wawancara awal yang dilakukan peneliti, diketahui bahwa A dan B cenderung melakukan emotionfocused coping sebagai strategi koping yang dipilihnya.

Penelitian yang dilakukan Bouteyre, Maurel dan Bernaud (2007) menemukan bahwa problem-focused coping berkorelasi negatif dengan depresi. Penggunaan problem-focused coping dapat membantu seseorang mengurangi depresi yang dialami karena usaha secara langsung yang 
dilakukan untuk mengatasi stresor penyebab depresi. Penelitian tersebut juga menemukan bahwa emotion-focused coping berkorelasi positif dengan depresi. Bereaksi dengan emotion-focused coping dapat memperpanjang dan memperburuk efek dari situasi buruk yang dihadapi dan dapat mendorong timbulnya gejala depresi.

Berdasarkan penjelasan di atas, penelitian ini dilakukan untuk mengetahui peran kematangan emosi, problemfocused coping, dan emotion-focused coping terhadap kecenderungan depresi pada mahasiswa tahun pertama, khususnya di DIY. Hipotesis yang diajukan dalam penelitian ini adalah "Kematangan emosi, problem-focused coping, dan emotion-focused coping berkontribusi terhadap kecenderungan depresi pada mahasiswa tahun pertama di DIY".

\section{Metode}

Subjek yang digunakan dalam penelitian ini adalah 214 mahasiswa D3 maupun S1 yang sedang menempuh tahun pertama (angkatan 2016) di perguruan tinggi yang ada di DIY. Karakteristik subjek adalah mahasiswa tahun pertama yang berdomisili di DIY selama menempuh pendidikan tinggi dan berjenis kelamin laki-laki atau perempuan. Peneliti memilih DIY sebagai cakupan penelitian karena merupakan salah satu provinsi yang menjadi tujuan untuk melanjutkan pendidikan perguruan tinggi.

Instrumen pengumpulan data yang digunakan dalam penelitian ini adalah dengan menggunakan skala. Penyebaran dan pengisian skala dilakukan secara online. Terdapat tiga skala yang digunakan dalam penelitian, yaitu Skala Kematangan Emosi, Skala Koping, dan BDI-II.

\section{Kematangan emosi}

Variabel kematangan emosi diukur dengan menggunakan Skala Kematangan Emosi milik Rizqi (2009). Skala ini disusun berdasarkan aspek kematangan emosi milik Katkovsky dan Gorlow yang terdiri dari tujuh aspek, yaitu kemandirian, kemampuan menerima kenyataan, kemampuan adaptasi, kemampuan merespon dengan tepat, merasa aman, kemampuan berempati, dan kemampuan menguasai amarah (Ais, 2014). Skala ini menggunakan 4 alternatif jawaban yang bergerak dari angka 1 sampai dengan 4 . Semakin tinggi skor yang didapatkan, maka menunjukkan kematangan emosi yang baik, begitu pun sebaliknya.

Setelah dilakukan analisis pada data uji coba didapatkan koefisien korelasi aitem-total yang berada dibawah 0,250 sebanyak 13 aitem dari total keseluruhan aitem adalah 47 . Koefisien korelasi aitem bergerak dari -0,362 hingga 0,726. Azwar (2015) menyebutkan bahwa apabila aitem memiliki koefisien korelasi aitem-total sama dengan atau lebih besar dari 0,30, maka aitem-aitem tersebut dianggap memiliki daya diskriminasi yang memuaskan dan layak untuk dijadikan skala. Akan tetapi, koefisien korelasi aitem-total dapat diturunkan menjadi 0,25 jika terlalu banyak aitem yang terbuang apabila menggunakan koefisien korelasi aitem-total 0,30. Berdasarkan acuan tersebut, peneliti menggunakan koefisien korelasi aitem-total 0,25 . Aitem nomor 4 memiliki koefisien korelasi 0,223 dan aitem 25 memiliki koefisien korelasi 0,215. Kedua aitem tersebut tetap digunakan dalam penelitian ini, tetapi dengan dilakukan perubahan kalimat pada aitem tersebut. Nilai Alpha Cronbach setelah aitem 4 dan 25 dimasukkan pada skala kematangan emosi adalah 0,900 sehingga 
total aitem yang digunakan dalam penelitian adalah 36 aitem.

Strategi koping

Skala yang digunakan oleh peneliti untuk mengukur koping dalam penelitian ini adalah The Brief COPE dari tesis milik Ningrum (2011) yang sebelumnya sudah diadaptasi dari skala yang dibuat oleh Charles S. Carver pada tahun 1997. Skala ini merupakan skala versi singkat dari Skala COPE yang dibuat pula oleh Charles S. Carver, Jagdish Kumari Weintraub, dan Michael F. Scheier pada tahun 1989. Skala The Brief COPE terdiri atas 28 item dengan empat opsi $(1=$ Tidak pernah; 2 = Kadang; 3 = Sering; 4 = Selalu). Skala ini dikategorikan berdasarkan pendekatan problem-focused coping dan emotion-focused coping milik Lazarus dan Folkman. Hasil uji coba Skala The Brief COPE yang dilakukan oleh Ningrum menghasilkan 20 aitem yang memiliki daya diskriminasi tinggi. Reliabilitas ujicoba skala yang dilakukan oleh Ningrum menghasilkan nilai Alpha Cronbach diperoleh 0,701 untuk problem-focused coping dan 0,711 untuk emotion-focused coping. Semakin tinggi skor pada masing-masing dimensi menunjukkan bahwa semakin besar penggunaan strategi koping target.

Peneliti melakukan uji coba kembali pada 35 mahasiswa tahun pertama. Peneliti menggunakan koefisien korelasi aitem-total 0,25. Analisis pada data uji coba didapatkan koefisien korelasi aitemtotal yang berada dibawah 0,250 sebanyak 5 dari total keseluruhan jumlah aitem pada skala koping adalah 20 aitem. Koefisien korelasi aitem bergerak dari 0,552 hingga 0,789. Aitem nomor 15 memiliki koefisien korelasi 0,227. Akan tetapi, aitem tersebut tetap digunakan dalam penelitian ini dengan melakukan perubahan kalimat pada aitem tersebut sebelum dilakukan pengambilan data.
Nilai Alpha Cronbach skala koping setelah aitem 15 dimasukkan menjadi 0,885 sehingga total aitem yang digunakan dalam penelitian sebanyak 16 aitem.

Kecenderungan depresi

Peneliti menggunakan skala Beck Depresion Inventory-Second Edition (BDI-II) untuk mengukur kecenderungan depresi pada mahasiswa tahun pertama. Skala BDI-II terdiri dari 21 aitem yang mengukur simtom depresi yang dirasakan oleh seseorang (Beck, Steer, \& Brown dalam Ginting, et al., 2013) dan sudah banyak digunakan untuk mengidentifikasi depresi. Skala ini meliputi simtom Emotional Manifestation (Manifestasi Emosional), Cognitive Manifestation (Manifestasi Kognitif), Motivational Manifestation (Manifestasi Motivasi), dan Vegetative and Physical Manifestations (Manifestasi fisik dan vegetatif) yang dibagi dalam dua dimensi, yaitu kognitifafektif dan somatik (Whisman, Perez \& Ramel, 2000).

Setiap respons dari skala ini bergerak dari nilai 0 (tidak) sampai dengan 3 (berat) (Ginting, et al., 2013). Penyataan paling sesuai dengan indikator depresi memiliki skor paling tinggi. Sementara pada item nomor 16 dan nomor 18 memuat 7 pilihan jawaban namun masih tetap dengan nilai yang bergerak dari 0 sampai dengan 3 . Ginting, et al. (2013) dalam penelitiannya sudah melakukan uji coba skala ini pada subjek dengan kriteria yang sama dengan peneliti, yaitu mahasiswa di Indonesia. Hasil penelitian yang dilakukan oleh Ginting, et al. (2013) tersebut melaporkan bahwa reliabilitas dari Skala BDI-II versi Bahasa Indonesia yang sudah diuji cobakan dapat diterima dengan koefisien Alpha Cronbach 0,900. Berdasarkan hasil tersebut, peneliti tidak lagi melakukan uji 
coba pada skala BDI-II Bahasa Indonesia ini.

Sebelum melakukan pengisian skala, terlebih dahulu subjek mengisi kolom kesediaan untuk menjadi responden dalam penelitian agar dapat melanjutkan untuk mengisi skala. Setelah mengisi kesediaan dengan memberikan tanda centang, subjek kemudian dapat mulai mengerjakan skala peneliti yang terdiri dari tiga alat ukur (kematangan emosi, strategi koping, dan kecenderungan depresi) dengan terlebih dahulu melengkapi kolom identitas. Hasil isian subjek untuk masing-masing alat ukur kemudian dijumlahkan, sehingga didapat skor total untuk masing-masing alat ukur. Skor total inilah yang digunakan dalam analisis data. Untuk menguji hipotesis, peneliti menggunakan teknik regresi linier berganda (multiple regression), yang akan menghasilkan sebuah model linear dengan tiga variabel independen (kematangan emosi, problem-focused coping, dan emotion-focused coping) terhadap variabel dependen (kecenderungan depresi).

\section{Hasil}

\section{Deskripsi data}

Berdasarkan data yang diperoleh pada tabel 1 diketahui bahwa sebagian besar subjek tidak mengalami depresi atau dalam kondisi normal, yaitu sebanyak 101 subjek atau 47,1\%, 53 subjek atau 24,8\% berada dalam kategori depresi ringan, 43 subjek atau 20,1\% berada dalam kategori depresi sedang, dan sebanyak 17 orang subjek atau sebesar 7,9\% berada dalam kategori depresi berat.

\section{Uji asumsi}

Sebelum dilakukan uji hipotesis, perlu dilakukan uji asumsi sebagai prasya-rat agar analisis yang dihasilkan dapat berfungsi dengan optimal. Uji asumsi terdiri dari uji normalitas, uji linearitas, dan uji multikolinearitas. Data dikatakan normal apabila K-SZ positif dan memiliki taraf signifikansi $p>0,05$. Hasil uji normalitas residual pada data penelitian diperoleh nilai K-SZ sebesar 0,718 dan signifikansi sebesar 0,681. Hal ini menunjukkan bahwa data penelitian dapat dikatakan normal.

Untuk menguji linieritas, penguji menggunakan nilai $F$ untuk setiap pasangan variabel independen dan dependen. Hubungan antarvariabel dikatakan linier apabila memiliki nilai deviation from linearity tidak signifikan $(p>0,05)$. Hasil uji linieritas antara kecenderungan depresi dengan kematangan emosi, kecenderungan depresi dengan problem-focused coping, dan kecenderungan depresi dengan emotion-focused coping masingmasing memiliki skor deviation from linearity yang tidak signifikan $(p>0,05)$. Dengan demikian, dapat dikatakan bahwa hubungan antarvariabel penelitian linier.

Tabel 1.

Kategori Data Penelitian Variabel Kecenderungan Depresi

\begin{tabular}{lccc}
\hline \multicolumn{1}{c}{ Kategori } & Skor & Jumlah & Persentase (\%) \\
\hline $\begin{array}{l}\text { Normal/tidak ada gejala } \\
\text { depresi }\end{array}$ & $\mathrm{X}<14$ & 101 & 47,2 \\
$\begin{array}{l}\text { Depresi ringan } \\
\text { Depresi sedang }\end{array}$ & $14 \leq \mathrm{X}<20$ & 53 & 24,8 \\
$\begin{array}{l}\text { Depresi berat } \\
\text { Total }\end{array}$ & $20 \leq \mathrm{X}<29$ & 43 & 20,1 \\
110 & $29 \leq \mathrm{X}$ & 17 & 7,9 \\
\hline
\end{tabular}


Multikolinieritas dapat dilihat dari nilai tolerance dan Variance Infliation Factor (VIF). Field (dalam Nkuru, 2016) menyebutkan bahwa ketika nilai tolerance $>0,1$ atau VIF $<10$ pada variabel independen, maka tidak terjadi multikolinieritas. Kematangan emosi, problemfocused coping, dan emotion-focused coping memiliki nilai nilai tolerance $>0,1$ atau VIF $<10$ yang menunjukkan bahwa data tidak mengalami multikolinieritas.

\section{Uji hipotesis}

Uji hipotesis dilakukan dengan analisis linier berganda yang ditunjukkan pada tabel 2. Hasil analisis regresi berganda menunjukkan $\quad R^{2}=0,190 \quad$ dan $\quad F=16,472$ dengan $\mathrm{p}<0,05$. Koefisien determinasi $R^{2}$ sebesar 0,190 menunjukkan bahwa variabel kematangan emosi dan emotionfocused coping memberikan sumbangan sebesar $19 \%$ terhadap variabel kecenderungan depresi. Sisa $81 \%$ dijelaskan oleh variabel lain yang tidak diteliti. Nilai hitung pada tabel ANOVA menunjukkan $\mathrm{F}=16,472$ dengan signifikansi $<0,05$ yang berarti bahwa kematangan emosi, problem-focused coping, dan emotion-focused coping memiliki hubungan yang signifikan dengan kecenderungan depresi. Berdasarkan hasil analisis regresi tersebut, maka hipotesis

pertama dari penelitian ini diterima. kematangan emosi dengan kecenderungan depresi pada mahasiswa tahun pertama". Berdasarkan tabel koefisien pada hasil analisis regresi, tampak bahwa kematangan emosi memiliki $t=-6,026$ dengan taraf signifikansi di bawah 0,05 $(\mathrm{p}<0,05)$. Hal ini mengindikasikan bahwa kematangan emosi memiliki hubungan linier yang signifikan dan berkorelasi negatif dengan kecenderungan depresi. Oleh karena itu dapat disimpulkan bahwa hipotesis kedua diterima.

Berikutnya, hipotesis ketiga dan keempat dari penelitian ini menyatakan bahwa problem-focused coping berkorelasi negatif dengan kecenderungan depresi dan emotion-focused coping berkorelasi positif dengan kecenderungan depresi. Problem-focused coping memiliki $t=-0,557$ dengan taraf signifikansi lebih dari 0,05 yang berarti bahwa tidak ada hubungan antara problem-focused coping dengan kecenderungan depresi. Hasil signifikansi $p<0,05$ dengan $t=2,265$ pada emotion-focused coping menunjukkan adanya hubungan antara emotion-focused coping dengan kecenderungan depresi. Berdasarkan hasil di atas, hal ini mengindikasikan bahwa hipotesis ketiga ditolak dan hipotesis keempat diterima.

Peneliti melakukan analisis tambahan untuk melihat adanya perbedaan tingkat depresi berdasarkan jenis kelamin.

Tabel 2.

Hasil Uji Regresi

\begin{tabular}{|c|c|c|c|c|c|}
\hline & Beta & $\begin{array}{c}\text { Standar } \\
\text { Kesalahan }\end{array}$ & $\begin{array}{c}\text { Beta } \\
\text { Terstandar }\end{array}$ & $t$ & Sig. \\
\hline Konstanta & 43,290 & 6,351 & & 6,816 & ,000 \\
\hline Kematangan Emosi &,- 370 & 061 &,- 467 & $-6,026$ & ,000 \\
\hline Problem-focused Coping &,- 222 & 398 &,- 054 &,- 557 &, 578 \\
\hline Emotion-focused Coping & 469 & ,207 & 198 & 2,265 &, 025 \\
\hline
\end{tabular}


tailed) sebesar 0,228 dengan signifikansi $>0,05$. Hasil tersebut menunjukkan bahwa tidak terdapat perbedaan signifikan pada tingkat kecenderungan depresi pada lakilaki dan perempuan.

Analisis tambahan juga dilakukan untuk melihat ada tidaknya perbedaan dalam penggunaan strategi koping pada laki-laki dan perempuan. Uji MannWhitney dilakukan untuk melihat adanya perbedaan penggunaan problem-focused coping pada laki-laki dan perempuan. Berdasarkan hasil uji Mann-Whitney diketahui bahwa Asymp. Sig. (2-tailed) sebesar 0,882 dengan signifikansi >0,05. Hasil tersebut menunjukkan bahwa tidak terdapat perbedaan signifikan pada penggunaan problem-focused coping pada laki-laki dan perempuan. Uji t-test dilakukan untuk mengetahui perbedaan penggunaan emotion-focused coping pada laki-laki dan perempuan. Analisis t-test menghasilkan $t$ sebesar -2,705 dengan signifikansi $>0,05$. Kondisi ini menunjukkan bahwa tidak terdapat perbedaan penggunaan emotion-focused coping pada laki-laki dan perempuan.

\section{Diskusi}

Berdasarkan hasil analisis yang telah dilakukan, diketahui bahwa mayoritas mahasiswa tahun pertama (angkatan 2016) yang berpartisipasi dalam penelitian ini memiliki kematangan emosi yang tinggi (64,5\%). Jumlah subjek yang menggunakan problem-focused coping berada pada kategori tinggi (79\%), begitu pula dengan emotion-focused coping (79\%). Pada tingkat kecenderungan depresi, sebagian besar subjek berada pada keadaan normal atau tanpa gejala depresi $(47,2 \%)$, kemudian diikuti oleh depresi ringan $(24,8 \%)$, depresi sedang $(20,1 \%)$, dan terakhir depresi berat $(7,9 \%)$. Jika dilihat berdasarkan data tersebut, dapat diketahui bahwa jumlah subjek yang mengalami gejala depresi, baik ringan sampai dengan berat, berjumlah lebih dari $50 \%$ sehingga hal tersebut perlu untuk diwaspadai.

Hipotesis pertama yang diajukan dalam penelitian ini adalah terdapat hubungan antara kematangan emosi, problem-focused coping, dan emotion-focused coping dengan kecenderungan depresi pada mahasiswa tahun pertama di DIY. Analisis regresi berganda yang dilakukan menunjukkan $R^{2}=0,190$ dan $F=16,472$ dengan $p<0,05$. Berdasarkan hasil analisis tersebut, maka hipotesis pertama dalam penelitian ini diterima. Hasil analisis menunjukkan bahwa variabel-variabel independen tersebut berpengaruh sebanyak $19 \%$ terhadap kecenderungan depresi, sedangkan $81 \%$ yang lain tidak menjadi fokus dalam penelitian ini. Persentase tersebut menunjukkan bahwa selain kematangan emosi, problem-focused coping, dan emotion-focused coping, masih banyak faktor yang dapat menjadi penyebab terjadinya depresi.

Adanya hubungan antara kematangan emosi, problem-focused coping, dan emotion-focused coping sesuai dengan pernyataan Beck dan Alford (2009) yang menyebutkan bahwa kecenderungan depresi dapat disebabkan oleh banyak faktor. Durand dan Barlow (2013) membagi faktor-faktor yang memengaruhi kecenderungan depresi menjadi tiga, yaitu faktor biologis, faktor psikologis, dan faktor sosiokultural. Kematangan emosi, problem-focused coping, dan emotionfocused coping termasuk dalam faktor psikologis yang merupakan faktor internal munculnya kecenderungan depresi.

Dari hasil analisis tersebut, ditemukan persamaan regresi yang efektif adalah: 


$$
\mathrm{Y}=43,290-0,370 \mathrm{X}_{1}+0,469 \mathrm{X}_{3}
$$

Persamaan tersebut menunjukkan bahwa terdapat hubungan yang linier antara kematangan emosi dengan kecenderungan depresi. Tanda minus dalam persamaan tersebut menunjukkan bahwa terdapat hubungan yang negatif antara kematangan emosi dengan kecenderungan depresi, yaitu semakin tinggi kematangan emosi seseo-rang, maka semakin rendah tingkat kecenderungan depresi yang dialami. Hasil tersebut sejalan dengan penemuan Mahanta dan Kannan (2015) bahwa peningkatan kematangan emosi akan meningkatkan pula kemampuan penyesuaian diri pada mahasiswa tahun pertama. Individu dengan emosi yang matang mampu untuk mengontrol dan mengekspresikan emosinya disaat yang tepat dan dengan cara yang tepat sehingga dapat mengurangi kemungkinan untuk mengalami depresi. Beck (dalam Downing-Orr, 1998) dalam teorinya pun menyebutkan bahwa reaksi emosional individu berhubungan dengan penerimaan individu terhadap dunia yang dapat menjadi penyebab seseorang mengalami depresi. Data Seiffge-Krenke menjelaskan bahwa mahasiswa tahun pertama yang mulai memasuki masa remaja akhir sudah memiliki tingkat sosial kognitif yang lebih matang dan memikirkan konsekuensi yang akan timbul dari perilaku yang dilakukan (Lazarus, 1999).

Persamaan di atas juga menjelaskan bahwa terdapat pula hubungan antara emotion-focused coping dengan kecenderungan depresi. Tanda positif dalam persamaan menunjukkan bahwa terdapat hubungan positif antara emotion-focused coping dengan kecenderungan depresi yang berarti bahwa peningkatan penggu- naan emotion-focused coping berpengaruh terhadap peningkatan kecenderungan depresi. Hal ini sesuai dengan hasil penelitian Bouteyre, Maurel dan Bernaud (2007) yang menemukan bahwa emotionfocused coping berkorelasi positif dengan depresi. Bereaksi dengan emotion-focused coping dapat memperpanjang dan memperburuk efek dari situasi buruk yang dihadapi dan dapat mendorong timbulnya gejala depresi. Hal ini disebabkan karena penggunaan pola strategi koping yang maladaptif dapat memengaruhi fungsi intelektual individu. Singkatnya, penilaian dan proses koping yang mengontrol respon subjektif individu terhadap stres berpengaruh terhadap kinerja dan berakibat terhadap perubahan lingkungan eksternal (Dai \& Sternberg, 2004).

Akan tetapi, dalam persamaan tersebut tidak terdapat hubungan yang signifikan antara problem-focused coping dengan kecenderungan depresi sehingga koefisien regresi dari problem-focused coping tidak dicantumkan $(\mathrm{t}=-0,557$, $p>0,05)$. Hasil tersebut berlawanan dengan hasil penelitian yang dilakukan oleh Bouteyre, Maurel dan Bernaud (2007) yang menemukan bahwa problem-focused coping berkorelasi negatif dengan depresi. Penelitian tersebut menjelaskan bahwa penggunaan problem-focused coping dalam mengatasi masalah membantu seseorang untuk mengurangi depresi yang dialami karena usahanya untuk mengatasi permasalahan yang secara langsung meningkatkan stresor yang dapat menyebabkan depresi.

Penggunaan problem-focused coping seringkali digunakan oleh sebagian besar orang dalam mengatasi masalah dan dianggap efektif untuk mengurangi stress. Akan tetapi, individu akan cenderung untuk menggunakan strategi koping alter- 
natif apabila sumber stres yang dihadapi tidak jelas, pengetahuan mengenai modifikasi stres terbatas, atau bila hanya sedikit yang dapat dilakukan untuk mengurangi stres yang dirasakan (Dai \& Sternberg, 2004). Lazarus (1999) menambahkan bahwa emosi individu memberikan pengaruh dalam proses adaptasi dan bagaimana seseorang melakukan koping terhadap situasi yang dihadapi. Hal tersebut menjelaskan bahwa emosi yang terlibat ketika menghadapi masalah berpengaruh dengan tingkat stres dan adaptasi yang dapat memengaruhi pemilihan strategi koping individu. Pada mahasiswa tahun pertama, yang masih masuk dalam usia remaja, penggunaan strategi koping ini tidak banyak digunakan karena remaja belum memiliki kontrol terhadap perilaku yang dilakukan sebaik orang dewasa. Selain itu, penggunaan koping ini juga dapat membuat remaja merasa lebih tertekan karena ketidakmampuannya untuk melakukan tindakan berdasarkan informasi yang didapat untuk mengatasi stresor akibat adanya pengawasan dari orangtua (Ojala, 2013).

Horwitz, Hill, dan King (2010) menambahkan bahwa hasil yang tidak signifikan dapat terjadi karena strategi koping yang maladaptif memiliki pengaruh yang lebih besar terhadap kecenderungan depresi dibandingkan dengan strategi koping adaptif. Folkman dan Lazarus (Umayya, 2006; Taylor, 1998) menyebutkan bahwa mahasiswa memiliki kecenderungan menggunakan emotion-focused coping secara terus menerus, seperti meregulasi perasaan, mencari dukungan emosional dari orang lain, atau menghindar (secara kognisi maupun perilaku) dalam menghadapi situasi yang menekan tanpa menghadapi situasi tersebut secara langsung. Sebagai contoh, ketika dihadapkan pada tugas akademik, individu tidak langsung menghadapi masalah yang dihadapi, tetapi menunda dan akan menghindar dari tugas tersebut (Umayya, 2006; Ferrari et al., 1995). Perilaku tersebut akan membentuk perila$\mathrm{ku}$ menunda-nunda (Solomon \& Rothblum dalam Umayya, 2006), atau dikenal dengan istilah prokrastinasi, yang menyebabkan tugas dapat menumpuk. Penumpukan tugas yang terlalu banyak hingga tidak dapat ditangani dapat menjadi stresor yang jika tidak ditangani dapat mengarah pada gangguan depresi.

Analisis tambahan yang dilakukan oleh peneliti menemukan bahwa tidak terdapat perbedaan dalam tingkat kecenderungan depresi berdasarkan jenis kelamin. Piccinelli dan Wilkinson (2000) menyebutkan bahwa meski beberapa faktor yang melekat pada perempuan dapat memberikan pengaruh terhadap depresi sampai pada taraf tertentu, jenis kelamin masih belum dapat membuktikan adanya perbedaan tingkat gangguan depresi. Hal ini disebabkan karena terdapat faktor lain seperti peran sosial budaya, keterampilan koping, dan pengalaman traumatis di masa kecil yang lebih dapat menunjukkan adanya perbedaan tingkat depresi pada individu.

Peneliti juga menemukan bahwa tidak terdapat perbedaan penggunaan strategi koping, baik problem-focused coping maupun emotion-focused coping pada lakilaki dan perempuan. Pearlin dan Schooler (dalam Dai \& Sternberg, 2004) menyebutkan bahwa efektivitas strategi koping yang dilakukan bergantung pada sifat dari stresor, waktu yang dibutuhkan untuk transaksi, dan kemampuan individu untuk menggunakan koping tersebut. Dai dan Sternberg (2004) menambahkan bahwa perlu pula mempertimbangkan personal significance dari situasi yang dihadapi. Sebagai contoh, jika mengha- 
dapi masalah tidak dapat memberikan nilai adaptif, maka strategi koping seperti avoidance merupakan strategi koping yang lebih tepat. Hal tersebut menjelaskan bahwa faktor-faktor di atas lebih kuat dalam menentukan strategi koping yang digunakan individu dibandingkan dengan jenis kelamin.

Individu jarang untuk menggunakan hanya satu macam strategi koping, tetapi dengan menggabungkan beberapa macam strategi koping untuk mengatasi masalah yang dihadapi (Mayne \& Bonanno, 2001). Sejauh mana individu merasa terancam dan strategi yang akan digunakan bergantung pada penilaian individu mengenai kemampuan dan ketersediaan sumber untuk melakukan koping (Lazarus \& Folkman dalam Lo, 2002). Penelitian yang dilakukan oleh Lees dan Ellis menyebutkan bahwa strategi koping bergantung pada pengalaman dan karakteristik kepribadian ketika mengalami keadaan yang membuat stress (Lo, 2002).

\section{Kesimpulan}

Hasil penelitian ini menunjukkan bahwa kematangan emosi dan emotion-focused coping terbukti berpengaruh terhadap kecenderungan depresi sebesar 19\%, sedangkan $81 \%$ yang lain tidak menjadi fokus dalam penelitian ini. Hal tersebut menunjukkan bahwa kedua faktor tersebut berkontribusi pada terjadinya depresi. Kematangan emosi berkorelasi negatif dengan kecenderungan depresi yang berarti bahwa semakin tinggi kematangan emosi, maka kecenderungan depresi akan semakin bekurang. Lebih lanjut, emotion-focused coping diketahui berkorelasi positif dengan kecenderungan depresi yang berarti bahwa penggunaan emotion-focused coping berkorelasi dengan meningkatnya kecenderungan depresi.
Akan tetapi, problem-focused coping tidak berkorelasi dengan kecenderungan depresi.

Selain hasil utama, penelitian juga menyimpulkan beberapa hasil yang diperoleh dari analisis tambahan, yaitu tidak ditemukan adanya perbedaan kecenderungan depresi pada jenis kelamin. Hal tersebut menunjukkan bahwa masih banyak faktor lain yang lebih dapat menunjukkan adanya perbedaan tingkat depresi pada individu. Analisis tambahan juga menemukan bahwa tidak terdapat perbedaan antara laki-laki dan perempuan dalam penggunaan strategi koping, baik problem-focused coping maupun emotion-focused coping. Hal tersebut terjadi karena strategi koping yang digunakan oleh individu bergantung pada kemampuan dan ketersediaan sumber untuk melakukan koping. Selain itu, pengalaman dan karakteristik kepribadian juga mempengaruhi pemilihan strategi koping yang digunakan.

\section{Saran}

Tingkat depresi yang tinggi pada mahasiswa menunjukkan pentingnya intervensi untuk mengurangi prevalensi depresi. Berdasarkan data yang didapatkan oleh peneliti, lebih dari 50\% mahasiswa tahun pertama mengalami depresi, baik dalam kategori ringan sampai dengan berat. Hal ini mungkin dapat terjadi karena mahasiswa tahun pertama masih dalam proses penyesuaian dengan lingkungan kampus. Peneliti menyarankan kepada perguruan tinggi agar dapat memberikan informasi yang cukup bagi mahasiswa dalam menghadapi lingkungan baru, terutama lingkungan kampus, pada tahun pertama. Selain itu, dapat pula dilakukan pendampingan selama satu tahun pertama bagi mahasiswa baru untuk dapat menyesuaikan 
diri sehingga dapat menjadi individu yang lebih dewasa dalam bersikap. Hal ini diharapkan dapat membantu menurunkan kecenderungan depresi pada mahasiswa tahun pertama.

Selain itu, tingkat kecenderungan depresi yang tinggi pada mahasiswa tahun pertama menunjukkan pentingnya pelayanan kesehatan mental di perguruan tinggi. Peneliti menyarankan agar perguruan tinggi dapat lebih memberikan perhatian terkait depresi di kalangan mahasiswa, khususnya mahasiswa tahun pertama, misalnya dengan menyediakan fasilitas pelayanan psikologis di wilayah kampus yang dapat diakses dengan mudah oleh mahasiswa.

Untuk penelitian selanjutnya, peneliti menyarankan agar persebaran subjek penelitian secara demografis lebih merata. Hal ini sebaiknya dilakukan agar tingkat kecenderungan depresi pada mahasiswa di DIY dapat lebih representatif. Selain itu, diperlukan pula alat ukur lain yang dapat digunakan untuk mengukur tingkat depresi agar data yang didapatkan lebih akurat. Saran lain untuk penelitian selanjutnya ialah melakukan pemilihan waktu yang tepat untuk pengambilan data agar data yang didapatkan lebih optimal.

\section{Daftar Pustaka}

Aditomo, A., \& Retnowati, S. (2004). Perfeksionisme, harga diri, dan kecenderungan depresi pada remaja akhir. Jurnal Psikologi, 1-14. doi: 10.22146/jpsi.7033

Asmika, Harijanto, \& Handayani, N. (2008). Prevalensi depresi dan gambaran stressor psikososial pada remaja Sekolah Menengah Umum di Wilayah Kotamadya Malang. Jurnal Kedokteran
Brawijaya, 15-22. doi: 10.21776/ub.jkb.2008.024.01.2

Azwar, S. (2015). Penyusunan skala psikologi edisi 2. Yogyakarta: Pustaka Pelajar.

Beck, A. T., \& Alford, B. A. (2009). Depression: Causes and treatment. Philadelphia: University of Pennsylvania Press.

Bouteyre, E., Maurel, M., \& Bernaud, J.-L. (2007). Daily hassles and depressive symptoms among first year psychology students in France: The role of coping and social support. Stress and Health, 23(2), 93-99. doi: $10.1002 /$ smi.1125

Dai, D. Y., \& Sternberg, R. J. (2004). Motivation, emotion, and cognition: Integrative perspectives on intellectual functioning and development. London: Lawrence Erlbaum Associates.

Darmayanti, N. (2008). Meta-analisis: Gender dan depresi pada remaja. Jurnal Psikologi, 35(2), 164-180. doi: 10.22146/jpsi.7950

Dobson, K. S., \& Dozois, D. J. (2008). Risk factors in depression. Amsterdam: Elsevier.

Downing-Orr, K. (1998). Rethinking depression: Why current treatments fail. New York: Springer Science+Business Media.

Durand, V. M. \& Barlow, D. H. (2013). Essentials of abnormal psychology 6 th ed. Wadsworth: Cengage Learning.

Dyson, R., \& Renk, K. (2006). Freshman adaptation to university life: Depressive symptoms, stress, and coping. Journal of Clinical Psychology, 62(10), 1231-1244. doi: 10.1002/jclp.20295

Ginting, H., Näring, G., van der Veld, W. M., Srisayekti, W., \& Becker, E. S. (2013). Validating the Beck Depression Inventory-II in 
Indonesia's general population and coronary heart disease patients. International Journal of Clinical and Health Psychology, 13(3), 235-242. doi: 10.1016/S16972600(13)70028-0

Hurlock, E. B. (1999). Psikologi perkembangan: Suatu pendekatan sepanjang rentang kehidupan. (Istiwidayanti, \& Soedjarwo, Trans.) Jakarta: Erlangga.

Ikatan Dokter Indonesia (IDI). (2016, Oktober 12). Hari kesehatan jiwa sedunia: Penyebab munculnya gangguan kesehatan jiwa. Retrieved from Ikatan Dokter Indonesia: http://www.idionline.org/berita/ha ri-kesehatan-jiwa-seduniapenyebab-munculnya-gangguankesehatan-jiwa/.

Lazarus, R. S. (1999). Stress and emotion. New York: Springer Publishing Company.

Lo, R. (2002). A longitudinal study of perceived level of stress, coping, and self-esteem of undergraduate nursing students an australian case study. Journal of Advanced Nursing, 39(2), 119-126. doi: 10.1046/j.13652648.2000.02251.x

Mahanta, D., \& Kannan, V. (2015). Emotional maturity and adjustment in first year undergraduate of Delhi University: An empirical study. Indian Journal of Psychological Science, 5(2), 84-90. Retrieved from http://www.napsindia.org/wpcontent/uploads/2017/05/13Dimpy-Mahanta-min.pdf.

Maslim, R. (2013). Buku saku diagnosis gangguan jiwa. Jakarta: PT. Nuh Jaya.

Mayne, T. J., \& Bonanno, G. A. (2001). Emotions: Current issues and future directions. New York: The Guilford Press.

McPhillips, D. (2016, September 14). U.S. among most depressed countries in the world. Retrieved from U.S. News: http://www.usnews.com/news/bes t-countries/articles/2016-09-14/the10-most-depressed-countries.

Mosley, T. H., Perrin, S. G., Neral, S. M., Dubbert, P. M., Grothues, C. A., \& Pinto, B. M. (1994). Stress, coping, and well-being among third-year medical students. Academic Medicine, (69)9, 765-767. doi: 10.1097/00001888-199409000-00024

Nagendra, K., Sanjay, D., Gouli, C., Kalappanavar, N. K., \& VinodKumar, C. S. (2012). Prevalence and association of depression and suicidal tendency among adolescent students. International Journal of Biomedical and Advance Research, 3(9), 714-719. doi: $10.7439 /$ ijbar.v3i9.72 6

Nkuru, F. N. (2016). Factors affecting growth of SACCOs within the agricultural sector in kenya: a case of meru farmers SACCOs. International Journal of Finance and Policy Analysis, 4(1), 34-45. Retrieved from http://gifre.org/library/upload/vol ume/34-45-FACTORS-vol-4-1gjcmp.pdf.

Ningrum, R. P. (2011). Peranan persepsi sakit dan strategi koping terhadap manajemen diri penyandang diabetes mellitus tipe 2. Tesis tidak diterbitkan, Universitas Gadjah Mada, Yogyakarta.

Ojala, M. (2013). Coping with climate change among adolescents: Implications for subjective wellbeing and environmental 
engagement. Sustainability 5(5), 2191-2209. doi: $10.3390 / \mathrm{su} 5052191$

Piccinelli, M., \& Wilkinson, G. (2000). Gender differences in depression. British Journal of Psychiatry, 177, 486-492. doi: 10.1192/bjp.177.6.486

Rani, V., Kamboj, S., Malik, A., \& Kohli, S. (2015). A study of emotional maturity in relation to selfconfidence and insecurity in adolescents. Indian Journal of Positive Psychology, 6(4), 393-396.

Rizqi, M. I. (2009). Pengaruh kematangan emosi terhadap kecenderungan self injury pada remaja. Skripsi tidak diterbitkan, Universitas Islam Negeri Syarif Hidayatullah, Jakarta.

Rosiana, D. (2011). Penyesuaian akademis mahasiswa tingkat pertama. Prosiding SNaPP, 2(1), 491-495. Retrived from http://proceeding.unisba.ac.id/ind ex.php/sosial/article/view/309/pdf.

Sharma, B. (2012). Adjustment and emotional maturity among first year college students. Pakistan Journal of Social and Clinical Psychology, 9(3), 32-37. Retrieved from
http://www.gcu.edu.pk/FullTextJo ur/PJSCS/2012july/5.pdf.

Taylor, S. (1998). Coping strategies. Retrieved from MacArthur: Research Network on SES: http://www.macses.ucsf.edu/resea rch/psychosocial/coping.php.

Umayya, S. H. (2006). Hubungan antara emotion-focused coping dengan prokrastinasi akademik pada mahasiswa. Skripsi tidak diterbitkan, Universitas Islam Indonesia, Yogyakarta.

WHO. (2016, April). Depression. Retrieved from World Health Organization: http://www.who.int/mediacentre/f actsheets/fs369/en/.

Whisman, M. A., Perez, J. E., \& Ramel, W. (2000). Factor structure of the Beck Depression Inventory-Second Edition (BDI-II) in a student sample. Journal of Clinical Psychology, 56(4), 545-551. doi: 10.1002/(SICI)10974679(200004)56:43.0.CO;2-U

Winnicott, D. W. (1990). The maturational processes and the facilitating environment: Studies in the theory of emotional development. New York: Karnac Books. 